\begin{tabular}{|c|c|c|}
\hline Beitr. Ent. & Keltern & ISSN 0005-805X \\
\hline $56(2006) 1$ & S. $199-212$ & 15.08 .2006 \\
\hline
\end{tabular}

\title{
Notes on the caddisfly fauna of Lake Matano in Central Sulawesi
}

\section{(Insecta, Trichoptera)}

With 32 figures

WOlfram Mey

\section{Zusammenfassung}

Eine kleine Aufsammlung von Köcherfliegen vom Lake Matano in Zentral Sulawesi enthielt insgesamt 14 Arten. Davon erwiesen sich zehn Arten als unbekannt. Sie werden hier beschrieben als: Agapetus tampulemensis sp. n., Chimarra glaubrechti sp. n., Hellyethira lacustris sp. n., Orthotrichia litoris sp. n., Ecnomus matanensis sp. n., Paduniella celebensis sp. n., Pseudoneureclipsis sorowakensis sp. n., Setodes leucocephalus sp. n., Setodes flexus sp. n. und Setodes rinteleni sp. n. Der Genitalapparat der Männchen wird abgebildet und auf die diagnostischen Merkmale hingewiesen.

\section{Summary}

Samples of the Trichoptera fauna of Lake Matano in Central Sulawesi contained a total of 14 species. Ten species proved to be unknown and are described as: Agapetus tampulemensis sp. n., Chimarra glaubrechti sp. n., Hellyethira lacustris sp. n., Orthotrichia litoris sp. n., Ecnomus matanensis sp. n., Paduniella celebensis sp. n., Pseudoneureclipsis sorowakensis sp. n., Setodes leucocephalus sp. n., Setodes flexus sp. n. and Setodes rinteleni $\mathrm{sp}$. $\mathrm{n}$. The male genitalia are illustrated and diagnostic characters are provided.

Key words

Insecta, Trichoptera, taxonomy, new species, Indonesia, Sulawesi, Lake Matano

\section{Introduction}

One of the interesting geographical features of Sulawesi (Indonesia) is the presence of large and deep lakes. They are situated in the central part of the island (Fig. 1), and comprise Lake Matano, Lake Towuti, and Lake Poso, to mention the larger ones. The lakes are rather old and their age is estimated to be 1-2 million years (RINTELEN et al. 2004). Since a couple of years the malacologists of the Museum für Naturkunde Berlin have been performed a research programme on the freshwater molluscs of these lakes. They are concerned mainly with the genus Tylomelania SARASIN \& SARASIN, 1897, which exhibit an interesting pattern of speciation and radiation (cf. RINTELEN \& GLAUBRECHT 2005). 


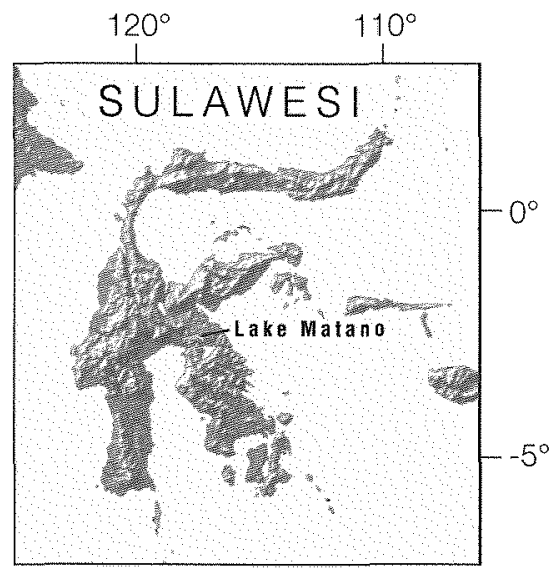

Fig. 1: Map of Sulawesi showing the location of Lake Matano.

The Trichoptera of the lakes are unstudied so far, and thus, largely unknown. Caddisflies are known for their ability to build up endemic species swarms in old lakes. Famous examples are Lake Baikal in Siberia or Lake Tanganyika in East Africa. Since the Sulawesi lakes are also of considerable age, caddisflies could have been able to adapt to the lake conditions and developed intra-lacustrine radiations in some genera.

The author took the opportunity to address this question and joined the malacologists research team in October 2005. The team was based in Soroako on Lake Matano. The sampling of caddisflies was concentrated on this lake. On the southern shore in close vicinity to Soroako several lamp light collections and benthos samplings were performed. During the field work it soon became obvious that caddisflies and other aquatic insects occur in remarkably low numbers. Back in the museum the first impression of a poor community was corroborated by examining the collected material. The samples contained an unexpectedly small number of species. Only two caddisfly species proved to be dominant, the remainder consisted of rare species. Though most of the species turned out to be undescribed, they offered no clear hints towards the existence of a radiation pattern of particular groups. The material contained no unusual species nor an enrichment of species of a certain genus. Moreover, the faunal composition appears to be rather unequilibrated. There should be more species of Hydroptilidae, Polycentropodidae and Leptoceridae. An interpretation of the results is not possible at this stage. It is questionable whether the samples reflect the actual Trichoptera community or whether they are too much a fragment of a more diverse fauna. Even the existence of a intra-lacustrine radiation cannot be ruled out. It should be mentioned, that the region around the large lakes in Central Sulawesi belongs to an extensive area of ultramafic rock outcrops (DAvrs et al. 1995). The high concentration of metals such as magnesium and nickel together with the nutrient-poor soils result in a low, scrubby vegetation that differs considerably from other rainforest regions in Sulawesi. The aquatic entomofauna of the lakes could be affected by the ultramafic soils directly or indirectly by altered food webs or food availabilities. Consequently, further samples collected in different seasons are necessary to clarify the questions. However, it is uncertain, whether the author will be able to visit the lakes again. Therefore, the results obtained so far are published here in order to save the data and to facilitate future investigations. 
Depository: The holotypes and paratypes of the species in alcohol are deposited in the Trichoptera collection of the Indonesian Institute of Sciences, Bogor (LIPI). The pinned material is housed in the Museum für Naturkunde, Berlin.

\section{List of collected species}

\section{Agapetus tampulemensis sp. $\mathbf{n}$.}

(Figs 2-3, 27)

Material: Holotype of Indonesia, Sulawesi Selatan, Soroako, Lake Matano, at light, 16.10.2005, leg. W. Mey. Paratypes: $49 \sigma^{\top} o^{\star}, 131$ o $q$, same region, Soroako, Koro Tampulemo, 13.10.2005; $40^{*}, 2$ q 9 , same region, Koro Lawewu, 12.10.2005, all leg. W. Mey.

Length of forewing 2,5-3 mm. Head and thorax brown, frons and setal warts light brown, vestiture brown, ocelli white, base of antenna yellow beneath, flagellomeres brown, with a slight annulation, maxillary and labial palps small, brown. Legs brown, spurs 0.4.4. Sternite V of abdomen without lateral filaments, sternite VI with ventral process. Forewings dark brown, with patches of yellow-brown hairs among the veins and in the apical cells, veins with erect yellow or black hairs, especially in the basal half. Hind wing dark drown. Venation of forewing with apical fork 1-5, hindwing with subcosta reaching beyond radial cross-vein, furcation of RS and $\mathrm{M} 1+2$ very small, cross-vein m-r present.

Male genitalia (Figs 2-3): Preanal appendages absent, inferior appendages evenly rounded at apex and with thin, black plates on margin. Segment X sclerotised and its lateral projections bent dorsad. Aedeagus with a pair of long paramers.

Female genitalia: Segment IX deeply excised, forming a small ventral and a broad dorsal part.

Derivatio nominis: Derived from the river Tampulemo, entering Lake Matanao in Soroako.

A. tampulemensis sp. n. shows no close affinities to any of the other Agapetus species known from Sulawesi (Neboiss \& Botosaneanu, 1988). The new species is easily identified by the unique morphology of the $10^{\text {th }}$ segment of the male genitalia. The absence of free preanal appendages and of tibial spurs of the forelegs are unusual traits among south-east Asian species.

The species is probably not an actual lake dweller. It is an abundant species in the tributaries and may occur only occasionally in the lake.

\section{Chimarra glaubrechti sp. n.}

(Figs 4-5, 28)

Material: Holotype o Indonesia, Sulawesi Selatan, Soroako, Lake Matano, at light, 15.10.2005, leg. W. Mey. Paratypes: $17 \sigma^{*}$, same region, Soroako, Koro Tampulemo, 13.10.2005, leg. W. Mey.

Length of forewing 4,2-4,6 mm. Head short, rounded dorsally, brown, setal warts yellow-brown, postocular parietal sclerite short, antennae brown, basal segments of labial 


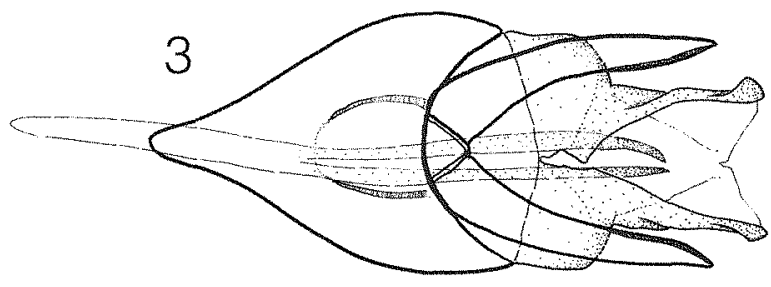

$0,5 \mathrm{~mm}$

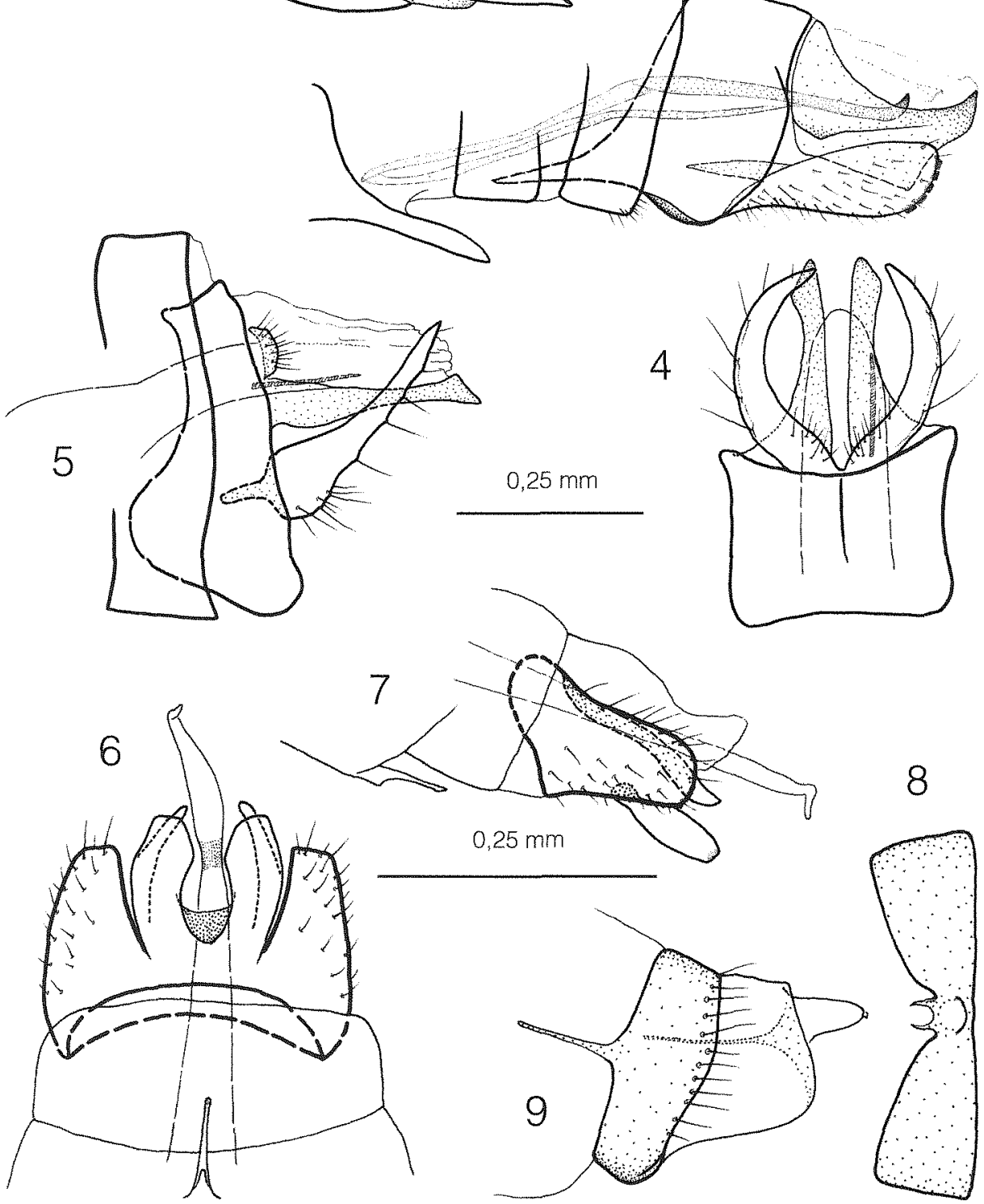

Figs 2-9: Male genitalia of: Agapetus tampulemensis sp. n., 2 - lateral, 3 - ventral; Chimarra glaubrechti sp. n., 4 - ventral, 5 - lateral; Hellyethira lacustris sp. n., 6 - ventral, 7 - lateral, 8 - female genitalia, segment IX, ventral, 9 - lateral. 
and maxillary palps yellow. Thorax brown, legs pale brown with darker spurs. Metatarsus of male foreleg enlarged, yellow-brown, spurs 1.4.4. Forewings more or less uniformly brown. Veins forming base of discoidal cell (= furcation of RS) thick and dark, wing area between median cell and RS before discoidal cell naked and membranous. Hindwings grey-brown, fork 3 very small.

Male genitalia (Figs 4-5): Segment IX in lateral view with sineous extension of anteroventral margin and with distinct apodemes, posteroventral process projecting. Tergum $\mathrm{X}$ membranous mesally, with two sclerotised lateral lobes, tips of lobes with a dorsal, subapical projection. Inferior appendages in lateral view elongate and nearly linear, in ventral view semi-circularly curved. Phallic apparatus with long phallotheca, one endothecal spine present.

Derivatio nominis: The specific name is in honour of my colleague Matthias Glaubrecht, who draw my attention to the Sulawesi lakes and offered the chance to participate in his field campaign.

The species is very similar to C. adnama MALICKx, 1993, described from Kotamobagu, North Sulawesi. The new species differs by the broader inferior appendages and by the much longer lateral lobes of segment 10 , which have characteristically formed tips. C. adnama occurs sympatrically with C. glaubrechti sp. $\mathrm{n}$. in the small rivers around Soroako. Like the preceding species $C$. glaubrechti sp. $\mathrm{n}$. is probably not an true lake dweller. It is an abundant species in the tributaries around Soroako.

\section{Oxyethira bogambara SCHMID, 1958}

Material: $1 \sigma^{7}$, Indonesia, Sulawesi Selatan, Soroako, Lake Matano, at light, 11.10.2005, leg. W. Mey.

The species occurs also in the rivers flowing into Lake Matano near Soroako.

\section{Hellyethira lacustris sp. n.}

Material: Holotype $0^{*}$ [pinned] and 3 o 9 paratypes, Indonesia, Sulawesi Selatan, Soroako, Lake Matano, at light, 11.10.2005, genitalia slides Mey 12/06 and 13/06, leg. W. Mey.

Length of forewing 2,1-2,2 $\mathrm{mm}$. Head pale brown, vestiture grey, antennae pale yellow, without annulations, maxillary palps pale brown. Thorax yellow-brown, with grey hairs on meso- and metanotum, legs pale yellow, spurs darker, tarsus with darker annulations, spurs 0.3.4. Sternum VII with acute process. Forewings yellow-grey and shining, with light brown areas between veins, costal margin with a fringe of black hairs, further patches of dark brown hairs at the end of the anal field on the dorsal margin, at bifurcation of $M$ and on the tip of the wings; at these patches with erect, stiff bristles. Fringe pale yellow. Hindwings pale yellow.

Male genitalia (Figs 6-7): Lateral sides of segment IX enlarged, forming elongate lobes, truncate in dorsal view. Dorsal lobe membranous. Inferior appendages bifid, with a dorsal lobe thin and stab-like. Tip of phallic apparatus a small hook, no paramers. 
Female genitalia (Figs. 8-9): Segment IX ring-like, with short apophyses on anterior margin, in ventral view constricted and forming a knob-like structure in the middle around genital opening.

Derivatio nominis: Derived from lacus (Latin) = lake.

$H$. lacustris sp. $\mathrm{n}$. is very similar to H. litita WeLls, 1990, also described from Sulawesi. It can be distinguished by the elongate lobes of segment IX, the shape of the inferior appendages, and the tip of the phallic apparatus. Also, the female genital morphology is different. Perhaps the new species has adapted to stagnant waters, and thus, is ecologically distinct from related species, all of them known from running waters.

\section{Orthotrichia menarika WeLLs, 1990}

Material: 1 ๙ึ, 1 \%, Indonesia, Sulawesi Selatan, Soroako, Lake Matano, at light, 11.15.10.2005, leg. W. Mey.

\section{Orthotrichia litoris sp. $\mathrm{n}$.}

Material: Holotype of [pinned], genitalia slide Mey 14/06, Indonesia, Sulawesi Selatan, Soroako, Lake Matano, at light, 11.10.2005, leg. W. Mey.

Paratype: 1 , same data as holotype.

Length of forewing $2,3 \mathrm{~mm}$. Head and palpi brown, vestiture pale grey, antenna yellow, with flattened and broad flagellomeres, apical third brown. Thorax and legs with spurs light brown, spurs 0.3.4. Forewings grey-brown, with indistinct yellow spots on end of $\mathrm{Sc}$, on pterostigma and around apex in the apical cells. Tip of forewing with a dark brown spot and brown fringe.

Bristles in the anal and medial area yellow, on subcosta and radial veins black. Hindwing grey-brown. Sternum VII with central process.

Male genitalia (Figs 10-12): Segment IX with a small sternum and a larger tergum. Dorsal plate with an asymmetrical central lobe and a spiniform lateral lobe. Inferior appendages asymmetrical, with a subapical hook only on right appendage. Phallic apparatus with a simply bent paramer.

Derivatio nominis: Derived from litus (Latin) $=$ shore.

The new species is a member of the $O$. costalis group and close to $O$. berbaring Wells $\&$ MaLICKY, 1997 from Sumatra. The inferior appendages of the new species and the dorsal plate have a slightly different form.

\section{Ecnomus putung CARTWRIGHT, 1992}

Material: $30^{\star} o^{\star}, 2$ 우, Indonesia, Sulawesi Selatan, Soroako, Lake Matano, at light, 11.10.2005, leg. W. Mey. 

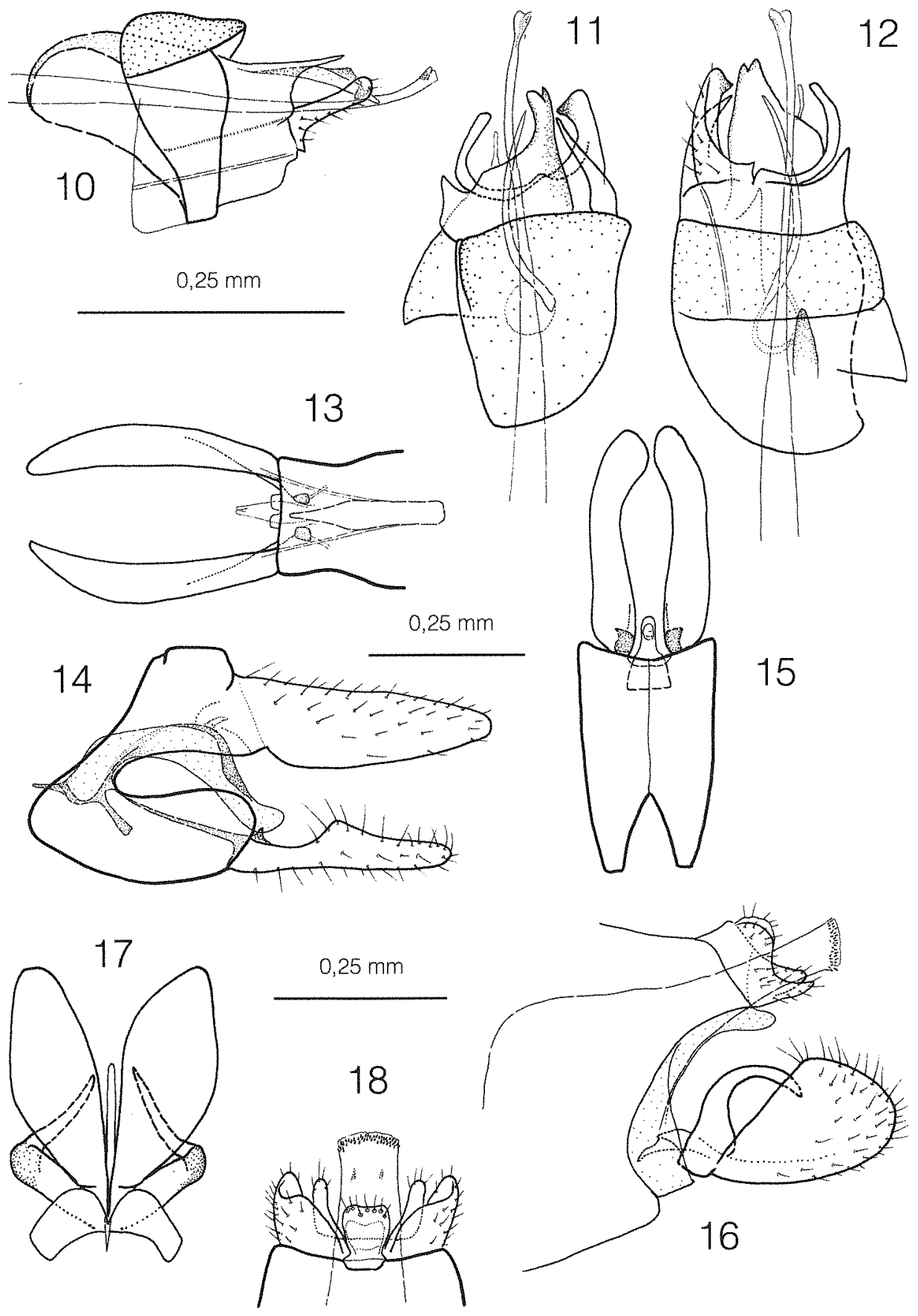

Figs 10-18: Male genitalia of: Orthotrichia litoris sp. n., 10 - lateral, 11 - dorsal, 12 - ventral; Ecnomus matanensis sp. n., 13 - dorsal, 14 - lateral, 15 - ventral; Pseudoneureclipsis sorowakensis sp. n., 16 - lateral, 17 - ventral, 18 - dorsal. 


\section{Ecnomus matanensis sp. $\mathrm{n}$.}

(Figs 13-15, 29)

Material: Holotype of [in alcohol] and 99 o $58 \%$ paratypes [partly pinned], Indonesia, Sulawesi Selatan, Soroako, Lake Matano, at light, 11.10.2005; $1 \sigma^{\text {, }}$, same region, Koro Lawewu, 12.10.2005, all leg. W. Mey.

Length of forewing 3,6-4,2 mm. Head brown, vestiture yellow, setal warts dark brown with dark brown setae, antennae pale yellow, with distinct annulations, maxillary palps brown. Thorax brown, with grey hairs on meso- and metanotum, prothorax darker, legs pale yellow, spurs not darker, tarsus with darker annulations, spurs 3.4.4. Abdomen yellow beneath, brown on dorsal side. Forewings with numerous yellow spots dispersed over the brown wing, a larger brown patch on pterostigma, costal margin with small spots of yellow hairs. Hindwings membranous, area between Rs and medial stem nearly naked.

Male genitalia (Figs 13-15): Superior appendages slightly longer than inferior appendages, without thick setae or teeth on apex. Inferior appendage a shallow band, in lateral view with a short, dorsad projection in the middle and a small acute hook at the base.

Derivatio nominis: Derived from the name of lake Matano.

CARTwRIght $(1992,1994)$ has described a number of Ecnomus species from Sulawesi. It was therefore somewhat surprising to find out, that this rather abundant species of Lake Matano was undescribed. It is probably a proper lake dweller because he was only once encountered on the several tributaries to the lake. The male genitalia of E. matanensis sp. n. are very peculiar and do not resemble any of the other species from Sulawesi.

\section{Pseudoneureclipsis sorowakensis sp. n.}

(Figs 16-18, 30)

Material: Holotype 0 and $7 \%$ paratypes, Indonesia, Sulawesi Selatan, Soroako, Lake Matano, at light, 11.-15.10.2005, leg. W. Mey.

Length of forewing $4,8-5,0 \mathrm{~mm}$. Head brown, vestiture yellow on vertex, brown on frons, posterior setal warts dark brown with dark brown setae, eyes hemispherical, black, antennae pale yellow, darker towards tips, with indistinct annulations, maxillary palps brown. Thorax brown, with grey hairs on warts and tegulae, prothorax darker, legs brown, spurs not darker, tarsus without distinct annulations, spurs 3.4.4. Abdomen yellow beneath, brown on dorsal side. Forewings uniformly light brown, fork 1 and 5 absent. Hindwings membranous, basal area nearly naked.

Male genitalia (Figs 16-18): Segment IX very narrow, divided in a dorsal and ventral part. Superior appendages as simple, short prolongations of segments IX and X. Inferior appendages short, nearly triangular in lateral view, basal hook with enlarged base and inwardly bent apical part. Phallic apparatus with a band of minute spines surrounding the opening of the phallotheca, two small, indistinct cornuti present.

Derivatio nominis: Derived from Soroako or Sorowako, the small town where the species was collected at the shore of Lake Matano. 
P. sorowakensis sp. $\mathrm{n}$. has similarities in the male genitalia with $P$. unguiculata ULmer, 1930 and $P$. infantae Mey, 2003 from the Philippines. The short inferior appendages are typical for this group. The new species differ from other species by the simple, semicircular form and arrangement of segments IX and X.

\section{Paduniella celebensis sp. n.}

Material: Holotype $\sigma^{\star}$ and $2 \sigma^{\star}, 1$ \& paratypes, Indonesia, Sulawesi Selatan, Soroako, Lake Matano, at light, 11.10.2005, leg. W. Mey.

Length of forewing 2,6-2,7 mm. Head brown, vestiture pale-grey, setal warts dark brown with dark brown setae, antennae pale yellow in basal third, with distinct annulations, flagellomeres brown in apical half, maxillary palps brown. Thorax brown, with grey hairs on meso- and metanotum, prothorax darker, legs pale yellow, spurs slightly darker, tarsus brown, without annulations, spurs 2.4.4. Abdomen yellow beneath, brown on dorsal side. Forewings uniformly golden brown, anal area paler brown. Hindwings membranous.

Male genitalia (Figs 19-20): Superior appendages elongate, but shorter than inferior appendages, without thick setae or teeth on apex. Inferior appendages with a broader base and a narrow, band-like apical part (harpago ?), in lateral view the base of the appendage bear some spines on the inner side. Phallic apparatus with a long dorsal paramer, and aedeagus with dorsal appendage, exceeding aedeagal tip, base of the phallic apparatus deeply inside preceding segments.

Derivatio nominis: Derived from Celebes, the older name of the island.

It is the first species of the genus to be described from Sulawesi. A species with a similar genitalic structure is $P$. angusta Banks, 1939 from Mindoro, Philippines.

\section{Setodes leucocephalus sp. n.}

(Figs 21-22, 31)

Material: Holotype o and $22 \sigma^{\star} 30 \% q$ paratypes, Indonesia, Sulawesi Selatan, Soroako, Lake Matano, at light, 11.10.2005. $21 \sigma^{\star}, 48$ 우, Sulawesi Selatan, Bantimurung, 9.10.2005, at light, all leg. W. Mey.

Forewing length 11,5-12 mm. Head pale grey, with patches of small white scales, setal warts grey, with white setae. Antennae white, articulations yellow, scape without hair pencil. Maxillary palpi light yellow. Thorax pale grey with small, white scales on mesonotum. Legs silky-white, spines on tarsi pale brown, spurs 1.2.2. Forewings light yellow, small spots of brown hairs dispersed over the wing and on the wing margin. Venation like in $S$. punctatus.

Male genitalia (Figs 21-22): Preanal appendages fused to segment $X$, visible as small prominence with numerous setae. Segment $X$ with a pair of long, black spines, directed ventrad and ending between the inferior appendages. Inferior appendages a broad, horizontal lobe, with a long, dorsad directed stab-like lobe on its base. Phallic apparatus simple, without paramers.

Derivatio nominis: Derived from leukokephalos (Greek) $=$ white-headed, referring to the white head of the adults. 


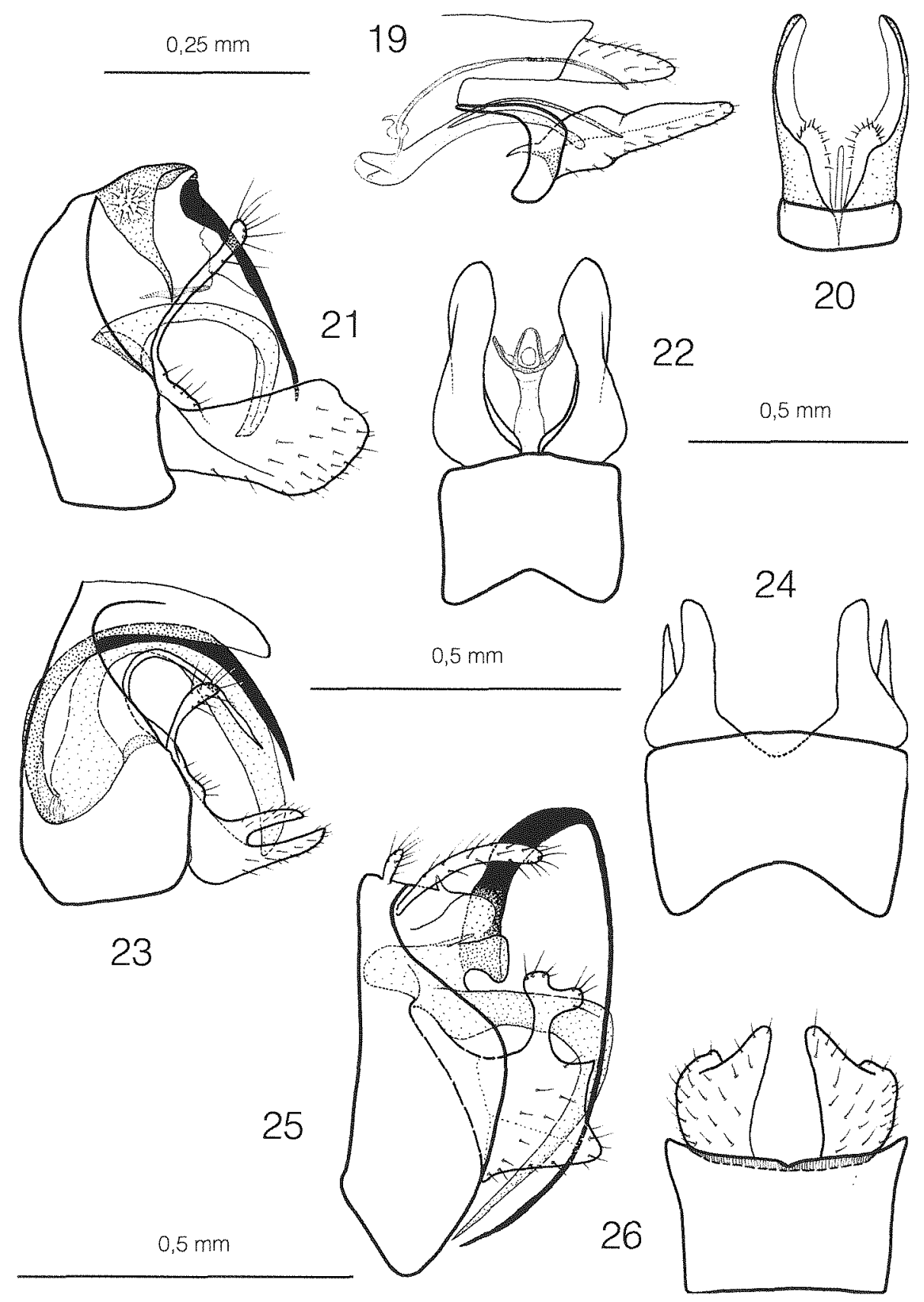

Figs 19-26: Male genitalia of: Paduniella celebensis sp. n., 19 - lateral, 20 - ventral; Setodes leucocephalus sp. n., 21 - lateral, 22 - ventral; Setodes flexus sp. n., 23 - lateral, 24 - ventral; Setodes rinteleni sp. n., 25 - lateral, 26 - ventral. 
S. leucocephalus sp. $\mathrm{n}$. is a rather isolated species. The male genitalia are very peculiar and do not resemble any other known species in SE Asia. The long, terminal processes of the 10th segment together with the reduced preanal appendages and the lacking paramers is a combination, which shows some resemblance to S. bhimachringa ScHMID, 1987 from South India. Interestingly, the Indian species is an inhabitant of stagnant waters too.

\section{Setodes flexus sp. n.}

Material: Holotype $\sigma^{*}$, Indonesia, Sulawesi Selatan, Soroako, Lake Matano, at light, 11.10.2005, leg. W. Mey.

Length of forewing $6.5 \mathrm{~mm}$. Head and thorax pale yellow, eyes black, antennae yellow, with thin, brown articulations, maxillary palpi light yellow. Forewing yellow, apex rounded.

Male genitalia (Figs 23-24): Preanal appendages absent. Segment X elongate triangular, without appendages. Inferior appendages with a horizontal lobe consisting of two parallel processes, and with two long, dorsad directed stab-like lobes on its base, the inner one is spine-like, semicircularly bent and running close to the aedeagus. Phallic apparatus with a broad aedeagus and long paramers.

Derivatio nominis: from flexus (Latin) $=$ curved, referring to the curved, dorsal processus of the inferior appendages.

The new species resembles S. venustus ULMER, 1951 and S. karnyi ULMER, 1930, both described from Sumatra. It differs by the lacking preanal appendages and by the form of the inferior appendages which have a long, semicircularly curved, dorsal processus. This character reminds to a similar structure found in Triaenodes.

\section{Setodes rinteleni sp. n.}

(Figs 25-26, 32)

Material: Holotype ${ }^{*}$ Indonesia, Sulawesi Selatan, Soroako, Lake Matano, at light, 11.10.2005, leg. W. Mey. Paratypes: $26 \sigma^{*} \sigma^{x}, 47 \%$, same region, Soroako, Koro Tampulemo, genitalia slide Mey 15/06, 13.10.2005, leg. W. Mey; $50^{\star} 0^{\star}, 3$ 우 ㅇ, Indonesia, Sulawesi, Kotamobagu, Torant Base Camp, 27.10.1985, leg. G. Zimmermann, in coll. Malicky.

Forewing length $4-5 \mathrm{~mm}$. Head pale grey-white with a medial, white line. Antennae white, articulations indistinct, brown, scape without hair pencil but with a broad, white line on dorsum which extends to pedicell and next flagellomeres. Maxillary palpi light brown. Thorax pale grey with golden hairs between the pair of white stripes on mesonotum. Legs grey-white, middle leg with a narrow brown line on outer side of tibia and tarsus. spurs 0.2.2. Abdomen green in females. Forewings with pointed apex, wing area covered with small golden hairs between small bands of white scales, these bands are lined with brown hairs. Hindwings hyaline. Venation like in $S$. punctatus.

Male genitalia (Figs 25-26): Segment IX with a short dorsal lobe. Preanal appendages long. Segment $\mathrm{X}$ short, attached to the base of paramers. Inferior appendages in lateral view nearly rectangular, with a short, dorsad directed process with two lobes. Phallic apparatus with acute aedeagus and characteristically curved paramers. 


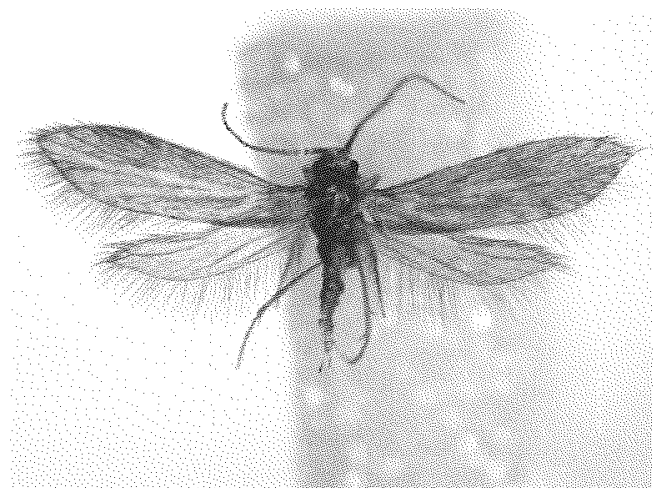

Fig. 27

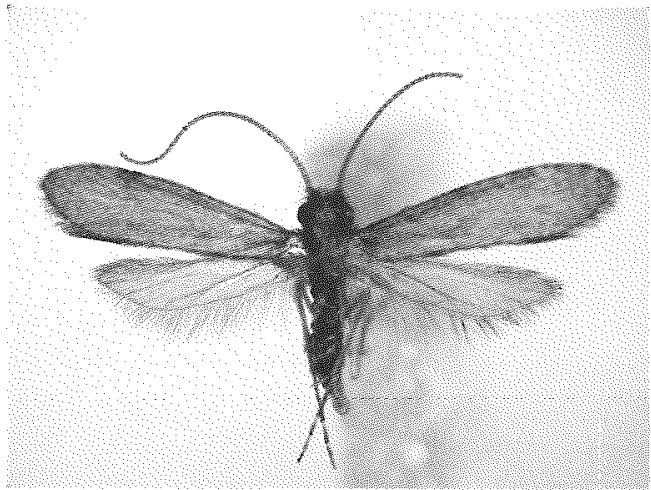

Fig. 29

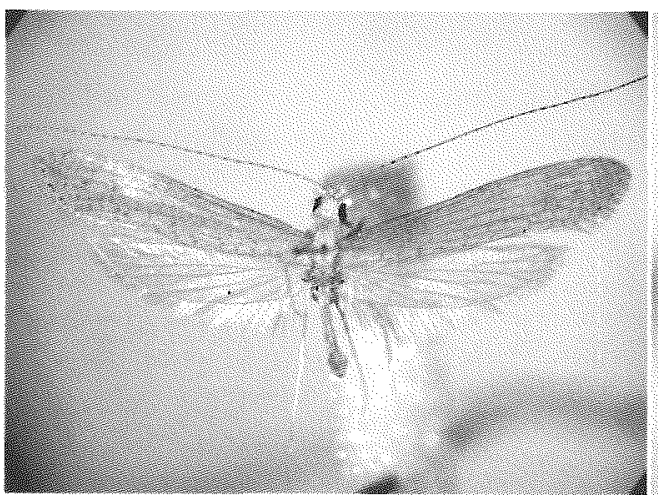

Fig. 31

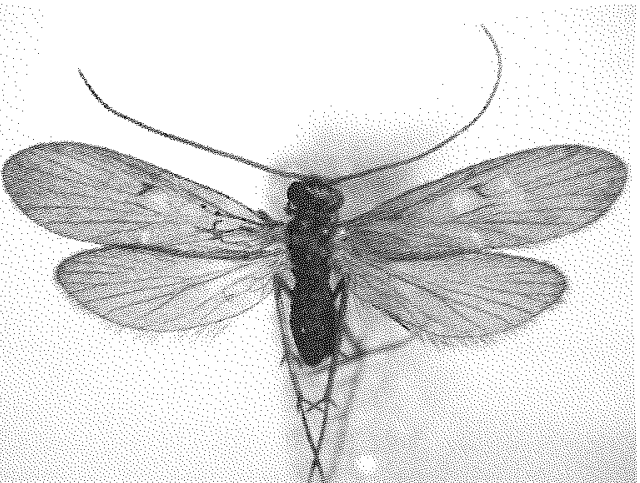

Fig. 28

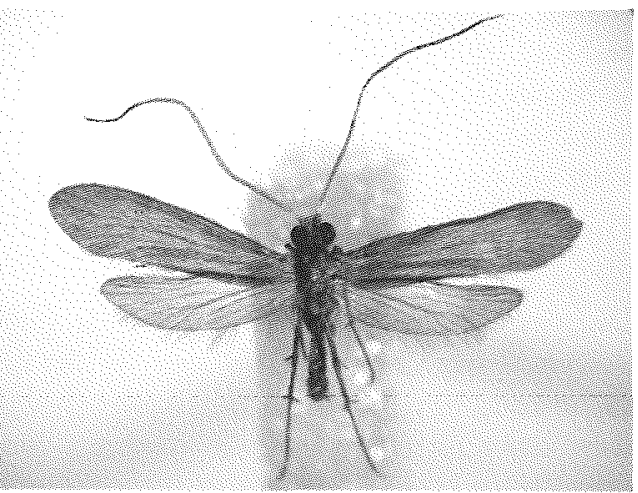

Fig. 30

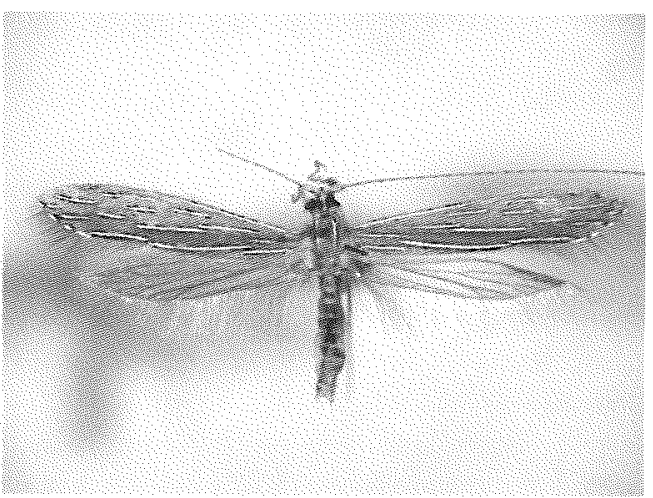

Fig. 32

Figs 27-32: Adults of: 27 - Agapetus tampulemensis sp. n., 28 - Chimarra glaubrechti sp. n., 29 - Ecnomus matanensis sp. n., 30 - Pseudoneureclipsis sorowakensis sp. n., 31 - Setodes leucocephalus sp. n., 32 - Setodes rinteleni sp. n. 
Derivatio nominis: The specific name is in honour of my colleague Thomas von Rintelen, who was very helpful in organising the journey of the author to Sulawesi.

The species is a member of the $S$. aparimeya-group and appears to be a close relative of S. mahabichu ScHmid, 1987 from India. Both species share the bifid, dorsal lobe of the inferior appendages and the elongate preanal appendages. $S$. rinteleni sp. n. differs by the acute aedeagus and by paramers, with a broad base and an abruptly bent, thin apical half.

\section{Oecetis tripunctata (Fabricius, 1793)}

Material: $1 \sigma^{*}$, Indonesia, Sulawesi Selatan, Soroako, Lake Matano, at light, 11.10.2005, leg. W. Mey.

O. tripunctata has a large range in SE Asia. In Indonesia it is known from Sumatra, Nias, Bali and Sulawesi. The species is closely related to Oecetis buitenzorgensis ULmer, 1951 decribed from Java and later recorded from New Guinea. It is questioanable whether both are distinct or one and the same species (MALICKY 2005).

\section{Acknowledgement}

I am grateful to my colleagues Dr. M. Glaubrecht and Dr. T. von Rintelen from the Museum für Naturkunde Berlin for their generously support of my field work in Sulawesi, and to Daisy Wowor (LIPI) for good company.

My thanks go to Hans Malicky who verified figures of the new species and to Jason Dunlop, who corrected the English text.

The research in Indonesia was supported by the Deutsche Forschungsgemeinschaft (Me 1085/5-3) and by a research permit granted by LIPI (Indonesian Institute of Sciences).

\section{References}

CARTWRTGHT, D. I. 1992: Description of four new species of Ecnomus MCLACHLAN (Trichoptera: Ecnomidae) from North Sulawesi. - Bulletin Zoologisch Museum, Universiteit van Amsterdam 13 (11): 101-108.

CARTwright, D. I. 1994: New species and new records of Ecnomus McLachlan (Trichoptera: Ecnomidae) from Indonesia. - Memoirs of the Museum of Victoria, Melbourne 54 (2): 447-459.

Davis, S. D.; HeYwood, V. H. \& Hamiton, A. C. 1995: Centres of Plant Diversity. A guide and strategy for their conservation. Volume 2: Asia, Australasia and the Pacific. - IUCN Publications Unit, Cambridge, U.K.: 578 pp.

MaLicky, H. 1993: Neue asiatische Köcherfliegen (Trichoptera: Philopotamidae, Polycentropodidae, Psychomyidae, Ecnomidae, Hydropsychidae, Leptoceridae). - Linzer biologische Beiträge 25 (2): 10991136.

MaLICKY, H. 1998: Köcherfliegen (Trichoptera) von Java und Sumatra, mit Revision einiger Ulmer-Typen aus dem Hamburger Museum. - Linzer biologische Beiträge 30 (2): 795-814.

MaLICKY, H. 2005: Beitrag zur Kenntnis asiatischer Oecetis (Trichoptera, Leptoceridae). - Linzer biologische Beiträge 37 (1): 605-669.

Mex, W. 2003: Contributions to the knowledge of the Caddisfly fauna of the Philippines, V (Insecta, Trichoptera). - Insecta Koreana, Chuncheon 20 (3/4): 425-452.

Neboiss, A. 1986: Atlas of Trichoptera of the SW Pacific-Australian Region. - Dr. W. Junk Publishers, Dordrecht: VIII + $286 \mathrm{pp}$. 
Neborss, A. 1987: Preliminary comparison of New Guinea Trichoptera with the faunas of Sulawesi and Cape York Peninsula. - p. 103-108. - In: Bournaud, M. \& H. Tachet (eds.): Proceedings of the fifth International Symposium on Trichoptera, Lyon, Dr. W. Junk Publishers, The Hague: XXIII +397 pp.

Nebotss, A. \& Botosaneant, L. 1988: Caddisflies (Trichoptera) of the families Rhyacophilidae, Hydrobiosidae and Glossosomatidae from Sulawesi. - Bulletin Zoologisch Museum, Universiteit van Amsterdam $11(20): 157-167$.

Rintelen, T. VON; WILSON, A. B.; MEYer, A. \& Glaubrecht, M. 2004: Escalation and trophic specialisation drive adaptive radiation of freshwater gastropods in ancient lakes on Sulawesi, Indonesia. - Proceedings of the Royal Society of London, B 271: 2541-2549.

Rintelen, T. von \& GLavbrecht, M. 2005: Anatomy of an adaptive radiation: a unique reproductive strategy in the endemic freshwater gastropod Tylomelania (Cerithioidea: Pachychilidae) on Sulawesi, Indonesia and ist biogeographical implications. - Biological Journal of the Linnean Society, London 85: 513-542.

SCHMID, F. 1987: Considerations diverses sur quelques gentes Leptocerins (Trichoptera, Leptoceridae). - Bulletin de l'Institut Royal des Sciences Naturelles de Belgique, Entomologie, Bruxelles 57 ( supplement): $147 \mathrm{pp}$.

Urmer, G. 1930: Trichopteren von den Philippinen und von den Sunda-Inseln. - Treubia, Buitenzorg 11: $373-498$.

UlMer, G. 1951: Köcherfliegen (Trichopteren) von den Sunda-Inseln. Teil 1. - Archiv für Hydrobiologie / Supplementband, Stuttgart 19: 1-528.

Wells, A. 1990: The Micro-Caddisflies (Trichoptera: Hydroptilidae) of North Sulawesi. - Invertebrate Taxonomy, East Melbourne 1990 (3): 363-406.

WeLls, A. \& MALICKY, H. 1997: The micro-caddisflies of Sumatra and Java (Trichoptera: Hydroptilidae). - Linzer biologische Beiträge 29 (1): 173-202.

Author's address:

Dr. Wolfram Mey

Humboldt-Universität zu Berlin

Museum für Naturkunde

Curator of Lepidoptera / Trichoptera

Invalidenstrasse 43

D - 10115 Berlin

Germany 